\title{
Рекомендації начальнику відділу прикордонної служби під час організації спеціальних дій щодо пошуку правопорушників
}

\author{
Вадим Торічний * 1 А; Валерій Райко 2 А; Денис Захарчук 3 А; \\ Володимир Андрушко 4 А \\ А Національна академія Державної прикордонної служби України імені Богдана Хмельницького, м. Хмельницький, Україна
}

Received: September 5, 2021 | Revised: October 10, 2021 | Accepted: October 30, 2021

DOI: $10.33445 /$ sds.2021.11.5.4

\begin{abstract}
Анотація
У статті на підставі сучасних підходів модернізації охорони державного кордону та прикордонної практики проведено аналіз керівних документів, що регламентують організацію оперативно-службової діяльності відділу прикордонної служби. Визначено порядок організації та проведення спеціальних дій щодо пошуку правопорушників відділом прикордонної служби. Встановлено, що на даний період часу немає практичних рекомендацій начальнику відділу прикордонної служби, щодо завчасної підготовки, порядку організації та керівництва спеціальними діями щодо пошуку правопорушників на закріпленій ділянці відповідальності.

В умовах динамічного розвитку обстановки на державному кордоні виникають обставини, які потребують оперативного реагування та вчасної реалізації заходів щодо запобігання протиправній діяльності, а саме пошуку та затримання правопорушників. Практика виконання зазначених заходів на ділянці відповідальності відділів прикордонної служби в багатьох випадках свідчить про залежність успіху протидії протиправній діяльності від завчасної організації спеціальних дій. Разом з тим, виникає протиріччя між наявними можливостями порушників у здійсненні протиправної діяльності і спроможністю відділу прикордонної служби у проведенні спеціальних дій.

Пошук наукових шляхів вирішення цього протиріччя і визначає потребу більш ґрунтовного аналізу даної проблеми. Актуальність статті полягає у дослідженні напрацьованого практичного досвіду застосування в органах охорони державного кордону Державної прикордонної службі України сил та засобів відділу прикордонної служби при проведені спеціальних дій щодо пошуку правопорушників, усунення протиріч, які виникають в процесі завчасної підготовки, організації та ведення спеціальних дій по пошуку правопорушників відділом прикордонної служби.
\end{abstract}

Ключові слова: спеціальні дії, пошук правопорушників, відділ прикордонної служби, оперативно-службова діяльність.

\section{Постановка проблеми}

Україна є відносно молодою суверенною країною, яка будує свою державність у досить складних геополітичних і геостратегічних умовах взаємовпливу східно та західно-

\begin{abstract}
орієнтованих держав i ïx регіональних об'єднань.

De-facto геопросторове розташування України на "межі цивілізацій" та зовнішньополітична криза з Російською
\end{abstract}

\footnotetext{
1 * Corresponding author: доктор наук з державного управління, доцент кафедри, e-mail: thetorik@gmail.com, ORCID: 0000-0003-3336-6386

2 доктор педагогічних наук, професор, професор кафедри, e-mail: valeriy_raiko050860@ukr.net, ORCID: 0000-0003-2494-8472

3 кандидат військових наук, доцент кафедри, e-mail: den_zachar@i.ua, ORCID: 0000-0001-6051-305x

${ }^{4}$ кандидат військових наук, доцент кафедри, e-mail: avzzet@ukr.net, ORCID: 0000-0002-2135-1243
} 


\begin{tabular}{lcr}
\hline Федерацією & зумовили & незворотність \\
європейського & та
\end{tabular}
стратегічного курсу Українського народу. У рамках реалізації політики європейської та євроатлантичної інтеграції в Україні активно здійснюється адаптація ї̈ нормативноправової бази та сфер практичної діяльності до законодавства Європейського Союзу (далі - ЄC), до нормативних актів Організації Північноатлантичного договору (далі - НАТО) і найкращого досвіду їх інституцій.

Метою адаптації законодавства України до законодавства $€ C$ є досягнення відповідності правової системи України з урахуванням критеріїв, що висуваються ЄС до держав, які мають намір вступити до нього. Слід підкреслити, що забезпечення стабільності та безпеки на зовнішніх кордонах $\epsilon$ надзвичайно важливим питанням для $\in C$.

Сучасна практика забезпечення прикордонної безпеки України реалізується в умовах оновлення загальнодержавної системи захисту державного кордону (далі ДК). Також, необхідно враховувати той факт, що важливим чинником успішної інтеграції України до європейського безпекового простору залишається забезпечення систем прикордонної безпеки України та $Є С$, який у перспективі може бути частиною зовнішнього кордону Європейського Союзу.

\section{Аналіз останніх досліджень та публікацій}

Значний науковий внесок у дослідження проблем прикордонної безпеки зробили відомі вчені О. С. Андрощук, В. І. Баратюк, О. А. Біньковський, Ю. А. Дем'янюк, В. В. Залож, Ю. Б. Івашков, І. С. Катеринчук, В. А. Кириленко, Д. А. Купрієнко, Г. А. Магась, А. Б. Мисик, І. В. Морозов, В. О. Назаренко, Б. М. Олексієнко, В. В. Половніков, О. М. Ставицький, В. О. Торічний та ін.
Оприлюднені науковцями результати досліджень у переважній більшості розглядають питання прикордонної безпеки 3 позиції охорони та захисту державного кордону.

Разом із тим, прикордонне безпекове середовище перебуває у постійній динаміці, що актуалізує необхідність його регулярного моніторингу та вивчення.

\section{Постановка завдання}

Відпрацювати рекомендацій начальнику відділу прикордонної служби щодо удосконалення організації та керівництва спеціальними діями з пошуку правопорушників. Завдання наукового дослідження: проаналізувати нормативно- правову базу, щодо організації та ведення спеціальних дій; запропонувати алгоритм дій начальника ВПС під час організації спеціальних дій щодо пошуку правопорушників.

\section{Виклад основного матеріалу}

Правовою основою діяльності Державної прикордонної служби України $\in$ Конституція України, Закон України “Про державний кордон України", Закон України "Про Державну прикордонну службу України”, інші закони України, видані на їх виконання акти Президента України, Кабінету Міністрів України, а також міжнародні договори України, згода на обов'язковість яких, надана Верховною Радою України, а для її основних оперативно-службових ланок прикордонних загонів та їх основних підрозділів - відділів прикордонної служби, директиви, накази Адміністрації Державної прикордонної служби та регіонального управління, якому він підпорядкований, а також Статут Державної прикордонної служби України частина I (Прикордонний загін), Кримінальний кодекс України, Кримінально-процесуальний кодекс України, Кодекс України про адміністративні правопорушення, закони України “Про державний кордон України", “Про оперативно-розшукову діяльність", “Про 
державну таємницю”, Положення “Про організацію оперативно - службової діяльності відділом прикордонної служби" прикордонної служби України, накази начальника прикордонного загону.

Відповідно до закону України “Про Державну прикордонну службу України" [1] виконання функцій, які зазначені у частині першій 2 статті, $\epsilon$ оперативно-службовою діяльністю Державної прикордонної служби України, яка полягає у здійсненні комплексу спеціальних дій, спрямованих на боротьбу 3 тероризмом, організованою злочинністю, пошуку правопорушників, локалізації кризових ситуацій, забезпечення внутрішньої та власної безпеки, виконання інших спеціальних завдань, а також координації діяльності державних органів в інтересах охорони державного кордону. Їх зміст полягає у здійсненні комплексу узгоджених та взаємопов'язаних за метою, місцем, завданнями та часом спеціальних, військових, оперативних, прикордоннопредставницьких, режимних та інших дій, спрямованих на боротьбу з тероризмом, організованою злочинністю, пошук правопорушників, локалізацію кризових ситуацій, виконання інших спеціальних завдань $з$ охорони державного кордону [2]. Наведене визначення спеціальних заходів свідчить, що вони $\epsilon$ формою ОСД, притаманною прикордонному загону.

Якщо взяти до уваги вимоги Інструкції 3 організації ОСД відділу прикордонної служби ДПСУ, затвердженої наказом Адміністрації ДПСУ від 29.12.2009 р. № 1040 [3], яка регламентує порядок підготовки та ведення спеціальних заходів 3 пошуку правопорушників на ділянці відділу прикордонної служби, то більшість ії положень втратили чинність у зв'язку 3 реформуванням підрозділів охорони державного кордону (далі-ПОДК), а ті, що залишаються чинними, не в повній мірі відповідають сучасним реаліям ОСД ПОДК.

Дещо інше визначення, пропонують автори навчального посібника "Управління прикордонним підрозділом": спеціальні заходи на ділянці відділення інспекторів прикордонної служби (далі - ВІПС) з пошуку правопорушників - це дії сил і засобів ВІПС у складі відділу прикордонної служби, об'єднаних єдиним задумом, що проводяться з метою припинення правопорушення, якщо прикордонному наряду не вдалося припинити його самостійно [4, с. 43].

Своє бачення з цього приводу висловив інший науковець Ю. Б. Івашков. Він зауважив, що спеціальні заходи $є$ формою ОСД, яка більше стосується ланки "прикордонний загін - відділ прикордонної служби (далі - ВПС) " [2]. Враховуючи обмеженість можливостей сил і засобів ВІПС та ВПС для проведення спеціальних заходів 3 пошуку правопорушників та обмеженість району їх проведення ділянкою відповідальності ПОДК, вбачається, що для ВІПС та ВПС поняття "спеціальні заходи" є досить широким.

Відомо що на ВПС покладаються відповідні завдання, які чітко регламентовані розпорядчими документами. Виконання цих завдань $€$ ОСД ВПС. Оперативно-службова діяльність відділу прикордонної служби це комплекс оперативно-службових, режимних та інших заходів, спрямованих на реалізацію основних функцій Державної прикордонної служби України.

В Наказі МВС від 15.04.2016 №311 “Про затвердження Положення про відділ прикордонної служби Державної прикордонної служби України" одним із визначених завдань ВПС зазначено, що він бере участь у проведенні прикордонних (спільних) операцій, здійснює спеціальні дії щодо пошуку порушників законодавства України з прикордонних питань.

Така форма оперативно-службової діяльності як спеціальні заходи відділу прикордонної служби не визначена, хоч і виконує завдання спрямовані на боротьбу з тероризмом, організованою злочинністю, пошуку правопорушників, локалізації кризових ситуацій, забезпечення внутрішньої та власної безпеки, виконання інших 
спеціальних завдань, а також координації діяльності державних органів в інтересах охорони державного кордону. В Інструкції 3 організації оперативно-службової діяльності відділу прикордонної служби Державної прикордонної служби України яку затверджено наказом Голови Державної прикордонної служби України від 29 грудня 2009 року № 1040 окремим абзацом визначено, що під час виконання завдань 3 охорони кордону відділом можуть використовуватися інші форми оперативнослужбової діяльності, визначені нормативними актами Адміністрації Держприкордонслужби України.

Як одна з складових прикордонної служби, спеціальні дії щодо пошуку правопорушників не можуть проводитися заплановано в визначений час, на визначеній конкретній ділянці відповідальності ВПС. Для злагодженості їх проведення здійснюється завчасна підготовка, тренування та навчання персоналу пОДК, органів управління. Проведення спеціальних дій з пошуку правопорушників ВПС здійснюється за умов виникнення певних обставин, які детермінують зміни в обстановці на ділянці підпорядкування чи навіть кількох ВПС, одного чи двох стикових прикордонних загонів.

Аналіз результатів ОСД органів та підрозділів охорони державного кордону та особистий практичний досвід показав, що важливим аспектом для досягнення успіху під час проведення пошукових дій $\epsilon$ необхідність завчасної підготовки до їх проведення. Опрацювання послідовності дій начальника ВПС щодо розробки плану спеціальних дій з пошуку правопорушників необхідне і корисне для навчання слухачів та використання офіцерами першого року служби. Це сприяє тому, що жодна з вимог нормативно-правових актів з прикордонних питань, жодна важлива рекомендація не залишилися поза увагою начальника ВПС, полегшуючи тим самим прийняття ним рішень та забезпечуючи їх точне виконання.
Керівні документи ДПСУ визначають ряд дій, які необхідно проводити для досягнення успіху під час проведення спеціальних дій. До них відносяться: завчасна підготовка до проведення спеціальних дій; усебічне знання обстановки і випередження дій правопорушників; постійна і чітка взаємодія всіх сил і засобів; своєчасний маневр силами і засобами; раптовість та безперервність дій; безперервне, тверде, гнучке керування підрозділами і всебічне забезпечення їхніх дій. Серед визначених дій важливе місце посідає робота начальника ВПС щодо організація спеціальних дій. У відповідності до Інструкції 3 організації оперативнослужбової діяльності відділу прикордонної служби ДПсу, робота починається відразу після отримання даних про підготовку або здійснення правопорушення в зазначених умовах. Організація спеціальних дій полягає у прийнятті рішення, постановці завдань черговим силам, елементам службового порядку (а за потреби й окремим прикордонним нарядам), організації взаємодії, всебічному забезпеченні пошукових дій та управлінні.

Аналіз досвіду роботи начальників ВПС щодо організації спеціальних дій з пошуку правопорушників дозволив сформулювати наступну послідовність їх дій:

- перш за все, перед прийняттям рішення начальник відділу повинен всебічно оцінити обстановку, дії правопорушників, свої сили і засоби, місцеве населення, місцевість, пору року, час доби і стан погоди тощо;

- по-друге, на основі всебічного аналізу даних обстановки начальник відділу прикордонної служби відпрацьовує висновки з оцінки обстановки. У подальшому на основі сформованих висновків з оцінки обстановки начальник відділу визначає задум дій на проведення спеціальних дій 3 пошуку правопорушників.

В подальшому, затверджене рішення, начальник відділу здійснює постановку завдань елементам службового порядку. 
у подальшому начальник відділу організовує взаємодію, всебічне забезпечення пошукових дій та управління [5].

Актуальність даного питання обумовлена відсутністю єдності науково обґрунтованих поглядів і вимог нормативно-правових актів, які зачіпають теорію і практику як ведення спеціальних дій щодо пошуку правопорушників, так і управлінську діяльність начальника ВПС по його підготовці.

Структурні підрозділи органів охорони державного кордону, зокрема ВПС виконують завдання за призначенням в умовах швидко мінливої обстановки. Ці умови особливо проявляються при веденні спеціальних дій щодо пошуку правопорушників, успішний результат яких залежить від знань, навичок і умінь начальника ВПС, що реалізуються при виконанні своїх функціональних обов'язків, а також злагодженості роботи.

Рішення різноманітних і складних завдань спеціальних дій щодо пошуку право- порушників вимагає своєчасної підготовки пропозицій і здійснення стійкої, безперервної і твердої управлінської діяльності. Крім того, необхідне вміння безперервно і активно вести збір, аналіз, обробку інформації, що надходить, а також здійснювати прогнозування розвитку обстановки на ділянці і приймати особисті управлінські рішення при різкій зміні обстановці.

3 метою скорочення часу на організацію спеціальних дій щодо пошуку правопорушників проводиться їх завчасна підготовка. Для визначення переліку заходів, на яких необхідно зосередити основні зусилля при підготовці до спеціальних дій щодо пошуку правопорушників, слід поглиблено вивчити зміст даного поняття, для цього доцільно скористатися доопрацьованою дев'яти значною римською формулою (Табл. 1): 1. Коли? 2. Де? 3. Хто? 4. Що? 5. 3 якою метою? 6. За яких обставин? 7. Можливі наслідки? 8. Вирішив. 9.Прошу, пропоную.

Таблиця 1 - Перелік спеціальних дій щодо пошуку правопорушників, за дев'яти значною римською формулою

\begin{tabular}{|c|c|c|}
\hline № $3 / n$ & Зміст формули & $\begin{array}{c}\text { Розкриття змісту відповідно до спеціальних дій щодо пошуку } \\
\text { правопорушників }\end{array}$ \\
\hline 1. & Коли? & $\begin{array}{l}\text { Незважаючи на підготовку особового складу, ділянки, } \\
\text { підрозділів і органів управління, завжди присутній елемент } \\
\text { раптовості, тобто точне прогнозування порушення державного } \\
\text { кордону не представляється можливим. }\end{array}$ \\
\hline 2. & Де? & $\begin{array}{l}\text { Спеціальні дії щодо пошуку правопорушників здійснюється на } \\
\text { ділянці ВПС або сусіднього ВПС. }\end{array}$ \\
\hline 3. & Хто? & $\begin{array}{l}\text { В спеціальних діях щодо пошуку правопорушників беруть участь } \\
\text { військовослужбовці ВПС і різнорідні сили, з одного боку, } \\
\text { порушники державного кордону або інші розшукувані особи - } \\
\text { іншого. }\end{array}$ \\
\hline 4. & Що? & $\begin{array}{l}\text { При проведенні спеціальних дій щодо пошуку правопорушників } \\
\text { здійснюється комплекс військових, режимних, оперативно- } \\
\text { розшукових, прикордонно-представницьких та інших заходів. }\end{array}$ \\
\hline 5 . & 3 якою метою? & $\begin{array}{l}\text { Спеціальні дії щодо пошуку правопорушників проводиться } 3 \\
\text { метою затримання порушників та інших розшукуваних осіб. }\end{array}$ \\
\hline 6. & За яких обставин? & $\begin{array}{l}\text { Спеціальні дії щодо пошуку правопорушників ведуться при } \\
\text { різних умовах, обумовлених як об'єктивними, так і } \\
\text { суб'єктивними обставинами. }\end{array}$ \\
\hline 7. & Можливі наслідки? & Порушення прикордонної безпеки в різних формах прояву. \\
\hline 8. & Вирішив. & $\begin{array}{l}\text { Зміст рішення начальника ВПС на ведення спеціальних дій щодо } \\
\text { пошуку правопорушників. }\end{array}$ \\
\hline 9. & Прошу, пропоную. & Залучення резерву, підрозділів посилення. \\
\hline
\end{tabular}


Дана формула актуальна для будь-яких умов обстановки і дозволяє визначити перелік заходів, яких необхідно приділити особливу увагу при підготовці спеціальних дій щодо пошуку правопорушників.

Такими заходами будуть:

- посилення охорони державного кордону та своєчасне прикриття району майбутніх пошукових дій;

- підтримка постійної готовності підрозділів ВПС до участі в проведенні Висновки

Таким чином, без належної підготовки спеціальних дій щодо пошуку правопорушників неможливо домогтися успішного результату їх проведення. При цьому підготовка спеціальних дій щодо пошуку правопорушників залежить від обсягу знань, навичок і умінь кожного посадовця ВПС, рівня взаємодії між ними в процесі управлінської діяльності, злагодженості у виконанні завдань за призначенням.

Теоретична значимість

отриманих результатів - узагальнено підходи до організації підготовки та ведення спеціальних дій щодо пошуку правопорушників відділом прикордонної служби. Практично розроблено рекомендації начальнику відділу прикордонної служби по організації спеціальних дій щодо пошуку правопорушників відділом прикордонної служби.

На думку авторів матеріали статті, значно покращать успіх спеціальних дій щодо пошуку правопорушників, вміння, майстерність офіцерів підрозділів охорони

спеціальних дій щодо пошуку
правопорушників;

- забезпечення таємного проведення перегрупування підрозділів 3 висуненням окремих з них в район передбачуваних дій;

- інформування взаємодіючих сил i засобів;

- підготовка органів і пунктів управління до розгортання для роботи.

державного кордону в проведенні спеціальних дій щодо пошуку правопорушників. Також вони можуть бути використані в практичній діяльності начальників ВПС та при проведені досліджень щодо удосконалення управління підрозділом при проведені спеціальних дій.

Матеріали, викладені у статті, зможуть надати допомогу начальникам відділів прикордонної служби у плануванні та практичному здійснені спеціальних дій щодо пошуку правопорушників.

Пропонуємо напрямом подальших досліджень вважати удосконалення порядку організації та проведення спеціальних дій щодо пошуку правопорушників відділом прикордонної служби, а саме в контексті питання щодо завчасної підготовки. На даний період часу немає практичних рекомендацій щодо завчасної підготовки до проведення спеціальних дій щодо пошуку правопорушників відділом прикордонної служби.

\section{Список використаних джерел}

1. Про Державну прикордонну службу України : Закон України від 03 квітня 2003 року № 661-IV. URL: https://zakon.rada.gov.ua/laws/show/66115\#Text

2. Івашков Ю. Б. Форми та види оперативнослужбової діяльності Державної прикордонної служби України. Честь $i$ закон. 2017. № 2(6) С. 56-61. https://doi.org/10.33405/2078-
7480/2017/2/61/136604

3. Інструкція 3 організації оперативнослужбової діяльності відділу прикордонної служби Державної прикордонної служби України (затв. наказом Адміністрації Державної прикордонної служби України від 29.12.2009 р. 1040). Київ : АДПСУ, 2009.

4. Управління прикордонним підрозділом : навчальний посібник. Баратюк В. І., Каштелян С. О., Трембовецький О. Г. та ін. 
Хмельницький: Видавництво НАДПСУ, 2019. 332 c.

5. Березенський О. І. Аналіз умов та розробка алгоритму дій начальника відділу прикордонної служби при організації спеціальних заходів щодо пошуку правопорушників. Сучасні інформаційні технології у сфрері безпеки та оборони. 2013. № 2. С. 61-65.

6. Про затвердження Положення про орган охорони державного кордону Державної прикордонної служби України: Наказ МВС України №971 від30 листопада 2018 року.

7. Про затвердження Положення про відділ прикордонної служби Державної прикордонної служби України: Наказ МВС України №311 від 15 квітня 2016 року.

8. Братко А. В, Мисик А. Б. Роль Державної прикордонної служби України в системі воєнної безпеки в умовах гібридної війни. Честь і закон. 2021. № 1 (76). С. 5-10. https://doi.org/10.33405/2078-

7480/2021/1/76/229210
9. Братко А. В., Софіян Д. В., Ковальчук О. Р., Використання методик стратегічного аналізу при проведенні оборонного планування Державної прикордонної служби України. Journal of Scientific Papers "Social Development and Security», 2021. Vol. 11, №. 3. P. 79-88. https://doi.org/10.33445/sds.2021.11.3.8

10. Torichnyi V., Biletska T., Rybshchun O., Kupriyenko D., Ivashkov Y., Bratko A. Information and propaganda component of the Russian Federation hybrid aggression: conclusions for developed democratic countries on the experience of Ukraine. TRAMES. 2021. Vol. 25(75/70), №. 3. P. 355368. https//doi.org/10.3176/tr.2021.3.06

11. Bratko A., Oleshko D., Datskov A., Vychavka V., Olytskyi O., Balytskyi I. Use of the SWOT analysis in the field of national security planning. Emerging Science Journal. 2021. Vol. 5, №. 3. P. 330-337. https//doi.org/10.28991/esj-2021-01280

\section{Рекомендации начальнику отдела пограничной службы при организации специальных действий по поиску правонарушителей}

\section{Вадим Торичный * 1 А; Валерий Райко* 2 А; Денис Захарчук ${ }^{3}$; Владимир Андрушко 4 A}

* Corresponding author: ${ }^{1}$ доктор наук по государственному управлению, доцент кафедры, e-mail: thetorik@gmail.com, ORCID: 0000-0003-3336-6386 2 доктор педагогических наук, профессор, профессор кафедры, e-mail: valeriy_raiko050860@ukr.net, ORCID: 0000-0003-2494-8472

${ }^{3}$ кандидат военных наук, доцент кафедры, e-mail: den_zachar@i.ua, ORCID: 0000-0001-6051-305x

${ }^{4}$ кандидат военных наук, доцент кафедры, e-mail: avzzet@ukr.net, ORCID: 0000-0002-2135-1243

А Национальная академия Государственной пограничной службы Украины имени Богдана Хмельницкого, г. Хмельницкий, Украина

\section{Аннотация}

В статье на основании современных подходов модернизации охраны государственной границы и пограничной практики проведен анализ руководящих документов, регламентирующих организацию оперативно-служебной деятельности отдела пограничной службы. Определен порядок организации и проведения специальных действий по поиску правонарушителей отделом пограничной службы. Установлено, что на данный период времени нет практических рекомендаций начальнику отдела пограничной службы, по заблаговременной подготовки, порядка организации и руководства специальными действиями по поиску правонарушителей на закрепленном участке ответственности.

В условиях динамичного развития обстановки на государственной границе возникают обстоятельства, которые требуют оперативного реагирования и своевременной реализации мер по предотвращению противоправной деятельности, а именно поиска и 
задержания правонарушителей. Практика выполнения указанных мероприятий на участке ответственности отделов пограничной службы во многих случаях свидетельствует о зависимости успеха противодействия противоправной деятельности от заблаговременной организации специальных действий. Вместе с тем, возникает противоречие между имеющимися возможностями нарушителей в осуществлении противоправной деятельности и способностью отдела пограничной службы в проведении специальных действий.

Поиск научных путей решения этого противоречия и определяет потребность более глубокого анализа данной проблемы. Актуальность статьи заключается в исследовании наработанного практического опыта применения в органах охраны государственной границы Государственной пограничной службе Украины сил и средств отдела пограничной службы при проведении специальных действий по поиску правонарушителей, устранения противоречий, возникающих в процессе заблаговременной подготовки, организации и ведения специальных действий по поиску правонарушителей отделом пограничной службы.

Ключевые слова: специальные действия, поиск правонарушителей, отдел пограничной службы, оперативно-служебная деятельность.

\title{
Recommendations to the head of the border service department when organizing special search actions
}

\author{
Vadym Torichnyi ${ }^{1 \text { A; }}$ Valerii Raiko * 2 A; Denys Zaharchuk ${ }^{3}$ A; \\ Volodymyr Andrushko $4 \mathrm{~A}$ \\ * Corresponding author: ${ }^{1} \mathrm{Dr}$ of sciences in public administration, e-mail: thetorik@gmail.com, ORCID: 0000-0003-3336-6386 \\ ${ }^{2}$ Dr in pedagogics, professor, e-mail: valeriy_raiko050860@ukr.net, ORCID: 0000-0003-2494-8472 \\ 3 PhD in Military Sciences, Associate Professor, e-mail: den_zachar@i.ua, ORCID: 0000-0001-6051-305x \\ 4 PhD in Military Sciences, Associate Professor, e-mail: avzzet@ukr.net, ORCID: 0000-0002-2135-1243 \\ A National Academy of the State Border Guard Service of Ukraine named after Bohdan Khmelnitskyi, Khmelnitskyi, Ukraine
}

\begin{abstract}
This article is about the analysis of the guiding documents regulating the organization of operational and service activities of the border guard division on the basis of modern approaches to modernization of state border protection and border practice. The procedure for organizing and holding of special measures for search of offenders by border guard division is defined. It is found that for the given period of time there are no practical recommendations to the chief of border guard division, concerning deliberate preparation, the order of the organization and the management of special actions concerning search of offenders on the fixed area of responsibility.

In the conditions of dynamic development of the situation on the state border there are circumstances that require prompt response and timely implementation of measures to prevent illegal activities, namely the search and detention of offenders. The practice of implementing these measures in the area of responsibility of the border guard division in many cases indicates the dependence of the successful combating illegal activities on the deliberate organization of special measures. At the same time, there is a contradiction between the available capabilities of violators in carrying out illegal activities and the ability of the border guard division to carry out special measures.

The search for scientific ways to resolve this contradiction determines the need for a more thorough analysis of this problem. The relevance of the article lies in the study of practical experience as to the use of the border guard division forces and means (in border protection bodies of the State Border Guard Service of Ukraine) in conducting special measures to search
\end{abstract}


for offenders, eliminating contradictions that arise in the process of deliberate preparation, organization and conduct of special measures by the border guard division to find offenders.

Keywords: special measures, search for offenders, border guard division, operational and service activities.

\section{References}

1. Pro Derzhavnu prykordonnu sluzhbu Ukrayiny : Zakon Ukrayiny vid 03 kvitnya 2003 roku № 661-IV. Available from: https://zakon.rada.gov.ua/laws/show/66115\#Text

2. Ivashkov YU. B. (20217). Formy ta vydy operatyvno-sluzhbovoyi diyal'nosti Derzhavnoyi prykordonnoyi sluzhby Ukrayiny. Chest' i zakon. № 2(6) S. 56-61. DOI: $10.33405 / 2078$ 7480/2017/2/61/136604

3. Instruktsiya $z$ orhanizatsiyi operatyvnosluzhbovoyi diyal'nosti viddilu prykordonnoyi sluzhby Derzhavnoyi prykordonnoyi sluzhby Ukrayiny (zatv. nakazom Administratsiyi Derzhavnoyi prykordonnoyi sluzhby Ukrayiny vid 29.12.2009 r. 1040). Kyiv : ADPSU, 2009.

4. Upravlinnya prykordonnym pidrozdilom :navchal'nyy posibnyk. Baratyuk V. I., Kashtelyan S. O., Trembovets'kyy O. H. ta in. Khmel'nyts'kyy: Vydavnytstvo NADPSU, 2019. $332 \mathrm{~s}$.

5. Berezens'kyy O. I. Analiz umov ta rozrobka alhorytmu diy nachal'nyka viddilu prykordonnoyi sluzhby pry orhanizatsiyi spetsial'nykh zakhodiv shchodo poshuku pravoporushnykiv. Suchasni informatsiyni tekhnolohiyi u sferi bezpeky ta oborony. 2013. № 2. S. 61-65.

6. Pro zatverdzhennya Polozhennya pro orhan okhorony derzhavnoho kordonu Derzhavnoyi prykordonnoyi sluzhby Ukrayiny: Nakaz MVS Ukrayiny №971 vid30 lystopada 2018 roku.
7. Pro zatverdzhennya Polozhennya pro viddil prykordonnoyi sluzhby Derzhavnoyi prykordonnoyi sluzhby Ukrayiny: Nakaz MVS Ukrayiny №311 vid 15 kvitnya 2016 roku.

8. Bratko A. V, Mysyk A. B. (2021). Rol' Derzhavnoyi prykordonnoyi sluzhby Ukrayiny $\mathrm{v}$ systemi voyennoyi bezpeky $\mathrm{v}$ umovakh hibrydnoyi viyny. Chest' i zakon. № 1 (76). S. 5-10. DOI: 10.33405/20787480/2021/1/76/229210

9. Bratko A. V., Sofiyan D. V., Koval'chuk O. R. (2021). Vykorystannya metodyk stratehichnoho analizu pry provedenni oboronnoho planuvannya Derzhavnoyi prykordonnoyi sluzhby Ukrayiny. Journal of Scientific Papers "Social Development and Security", Vol. 11, №. 3. R. 79-88. DOI: 10.33445/sds.2021.11.3.8

10. Torichnyi V., Biletska T., Rybshchun O., Kupriyenko D., Ivashkov Y., Bratko A. (2021). Information and propaganda component of the Russian Federation hybrid aggression: conclusions for developed democratic countries on the experience of Ukraine. TRAMES. Vol. 25(75/70), №. 3. R. 355-368. DOI: $10.3176 /$ tr.2021.3.06

11. Bratko A., Oleshko D., Datskov A., Vychavka V., Olytskyi O., Balytskyi I. (2021). Use of the SWOT analysis in the field of national security planning. Emerging Science Journal. Vol. 5, №. 3. R. 330-337. DOI: 10.28991/esj-202101280 